\title{
Biological Activity of Extracts from Some Mediterranean Macrophytes
}

\author{
E. Ballesteros, D. Martín and M. J. Uriz \\ Centre d'Estudis Avançats de Blanes (C.S.I.C.), Cami de Santa Bàrbara s/n, E-17300 Blanes (Girona). Spain
}

(Accepted 3 September 1992)

\begin{abstract}
Seventy one species of marine macrophytes from the Central Mediterranean have been screened for the production of antibacterial, antifungal, antiviral, cytotoxic and antimitotic compounds. Sixty five of the species displayed some kind of activity and most of them were active on more than one organism or cell tested. Antifungal activity was the most widespread ( $70 \%$ of the plants), whilst the incidence of antibacterial activity was extraordinarily low ( $6 \%$ of the plants). Of the plants tested $21 \%$ showed antiviral activity, $35 \%$ were cytotoxic and nearly $50 \%$ had antimitotic properties. The maximum level of activity was found among the Chlorophyta; some members of the Bryopsidales (Flabellia petiolata, Caulerpa prolifera, Halimeda tuna) were the most active species. Most of the dominant species in Mediterranean phytobenthic communities (Corallina elongata, Lithophyllum lichenoides, Phyllophora crispa, Cystoseira spp., Halopteris spp., Codium spp., Halimeda tuna, Valonia utricularis, Posidonia oceanica, Zostera noltii and Cymodocea nodosa) exhibited strong antifungal properties.
\end{abstract}

\section{Introduction}

Marine plants have been repeatedly recognized as producers of biologically active substances. Specific studies on seaweeds, carried out in the Atlantic, Pacific and Indian oceans, have demonstrated antibacterial, antifungal and antiviral (e.g. Burkholder et al. 1960, Hornsey and Hide 1974, Naqui et al. 1990, Rinehart et al. 1981, Reichelt and Borowitzka 1983, Hodgson 1984) activities, as well as ichthyotoxicity (e. g. Paul and Fenical 1986), cytotoxicity (e.g. Paul and Fenical 1991) and antimitotic properties (e.g. Munro et al. 1991). Antibacterial, antifungal and antiviral activities have also been investigated in some Mediterranean algae (Berti et al. 1963, Khaleafa et al. 1975, Porzi and Minelli 1975, Caccamese and Azzolina 1979, Barbagallo et al. 1979 a, b, Serarols et al. 1982, Pesando and Caram 1984, Caccamese et al. $1980,1981,1985)$ and the seagrass Posidonia oceanica (Bernard and Clement 1983, Bernard and Pesando 1989).

The goal of this study was to increase the knowledge of the chemically-mediated bioactivity in the marine Mediterranean flora by examining its most represen- tative macrophytes, including species not previously tested, and performing antimitotic and cytotoxic tests.

\section{Material and Methods}

Samples were taken by SCUBA diving in October 1988 during a survey aboard the oceanographic vessel 'García del Cid'. The zones investigated included 27 sampling stations off the Balearic and Columbretes Archipelagos (Western Mediterranean). Each sampling station was sampled exhaustively on deep to shallow transects $4 \mathrm{~m}$ wide. The extensive sampling provided 71 species coming from the main phytobenthic communities present in the Western Mediterranean.

Species were identified on board, just after collection. Voucher specimens were preserved in $5 \%$ formaldehyde. Tests for biological activities were started within three hours of collection of the samples. A mixture of from two to four specimens of each species was used in the bioassays in order to reduce intraspecific variability due to uncontrolled exogenous causes. 
Small pieces ( $2 \mathrm{~g}$ wet weight) of various specimens of each species were drained for $1 \mathrm{~min}$, weighed, homogenized together in the proportion of $1 \mathrm{~g}$ of alga per $10 \mathrm{ml}$ of $3: 1$ methanol/toluene, and centrifuged (Rinehart et al. 1983). Sterile paper discs, $6 \mathrm{~mm}$ in diameter, were soaked with $10 \mu \mathrm{l}$ of the supernatant, air-dried and used in the activity assays.

Antibacterial and antifungal activities of the crude organic extracts were determined by the diffusion method (Bergquist and Bedford 1978, Thompson et al. 1985) on cultures of two strains of bacteria, Escherichia coli and Bacillus subtilis, and two of fungi, Candida albicans and Aspergillus niger. The nutrientagar plates were incubated overnight at $37^{\circ} \mathrm{C}$ and zones of inhibition around the discs were measured. The mean value of the inhibition zones on the two microorganisms used to test each type of antimicrobial activity was scored: (0) no growth inhibition, ( 1 , 2 and 3) inhibition zone less than $2 \mathrm{~mm}$, between 2 and $4 \mathrm{~mm}$, and more than $4 \mathrm{~mm}$ wide, respectively.

Antiviral tests were performed with herpes simplex virus, type I (HSV) cultured in kidney cells of monkey (CV-1), and with vesicular stomatitis virus (VSV) in kidney cells of hamster (BAK) as previously described (Schröder et al. 1981). Mean values of the zones of virus inhibition on the two viruses were scored as in the case of cytotoxic activity.

Antimitotic tests were performed on leukemic cells of mice (L1210) by determining the percentage of inhibition of cell growth. The assays were scored: $(0)$ no inhibition, (1) $1-25 \%$ inhibition, (2) $26-50 \%$ inhibition, and (3) $51-100 \%$ inhibition.

Cytotoxic tests were performed on kidney cells of monkey (CV-1) incubated for 3 days at $37^{\circ} \mathrm{C}$. Cytotoxicity was calculated by determining zones of cell inhibition (Rinehart et al. 1983) and graded: (0) no growth inhibition, (1) inhibition zone to $1 \mathrm{~mm},(2)$ inhibition zone from 1 to $2 \mathrm{~mm}$, and (3) inhibition zone from 2 to $4 \mathrm{~mm}$.

Control tests with the solvent were performed for every assay.

\section{Results and Discussion}

Table I summarizes the degree of bioactivity of each species. Among the 71 species tested, only 6 (Spirulina sp., Amphiroa beauvoisii, Peyssonnelia rubra, Polysiphonia subulifera, Phyllariopsis brevipes and Zonaria tournefortii) did not show any kind of activity, and only one (Flabellia petiolata) was active in all tests.
Antibacterial activity was extremely rare in the plants screened $(6 \%)$. Only the red alga Falkenbergia rufolanosa (tetrasporophyte of Asparagopsis armata Harvey) and the green algae Caulerpa prolifera, Flabellia petiolata and Palmophyllum crassum displayed antibacterial activity. Antibacterial activity found by other authors in Mediterranean seaweeds was considerably larger; it ranged between 13\% (Pesando and Caram 1984) and nearly 50\% (Barbagallo et al. 1979, Caccamese et al. 1981, 1985) of the species tested. No previous record of antibacterial activity for Palmophyllum crassum has been found in the literature, while Falkenbergia rufolanosa (Serarols et al. 1982, Pesando and Caram 1984), Flabellia petiolata (Paul and Fenical 1991) and Caulerpa prolifera (Caccamese and Azzolina 1979) were already known to exhibit strong antibacterial activity. Different species shown to be without antibacterial activity in our screening tests have been found to be active by other authors also working with Mediterranean specimens. Seasonal (Burkholder et al. 1960; Hornsey and Hide 1976) as well as geographical (Conover and Sieburth 1963, Caccamese et al. 1989) differences in activity could explain these dissimilarities.

Antifungal activity was widespread in all the groups and it amounted to $70 \%$ of the tested macrophytes. This extensive and high activity found in our samples had never been observed in other Mediterranean surveys (Caccamese and Azzolina 1979, Caccamese et al. 1980, 1985, Pesando and Caram 1984, Bernard and Pesando 1989). The most dominant plants in Mediterranean phytobentic communities such as the seagrasses, Cystoseira spp., Halopteris spp., Codium spp., Halimeda tuna, Corallina elongata and Mesophyllum lichenoides strongly inhibited the growth of fungi. Seasonal and geographical changes in activity must also be taken into account to explain differences between our results and those found by other authors. Nevertheless, no reasons seem to explain this high level of antifungal activity, coupled with a low level of antibacterial activity, exhibited by our samples.

Only $21 \%$ of the plants showed antiviral activity, and this was mainly concentrated in members of the Chlorophyta. Nevertheless, strong inhibition of viral growth was only found in the blue green alga Aphanocapsa littoralis, the encrusting coralline Lithophyllum expansum and the brown alga Cystoseira balearica. Antiviral activity in Mediterranean seaweeds has only been reported by Caccamese et al. $(1980,1981)$, who used tobacco mosaic virus (TMV) inoculated on tobacco plants. Although no conclusions can yet be drawn, it seems possible that there is a higher activity of Mediterranean macrophyte extracts against plant viruses than against animal viruses. 
Table 1. Activity levels of the species tested. The meaning of the activity indices are explained in the text. Activities: BAC, antibacterial; FUN, antifungal; AV, antiviral; CT, cytotoxic; AM, antimitotic.

\begin{tabular}{llllllll}
\hline Species & BAC & FUN & AV & CT & AM & \\
\hline
\end{tabular}

\section{Cyanophyta}

Aphanocapsa littoralis Hansgirg

Rivularia mesenterica Thuret

Spirulina sp.

$\begin{array}{lllll}0 & 1 & 3 & 1 & 1 \\ 0 & 2 & 1 & 1 & 0 \\ 0 & 0 & 0 & 0 & 0\end{array}$

Rhodophyta

Acrodiscus vidovichii (Meneghini) Zanardini

Amphiroa beauvoisii Lamouroux

Amphiroa cryptarthrodia Zanardini

Amphiroa rigida Lamouroux

Botryocladia botryoides (Wulfen) J. Feldmann

Corallina elongata Ellis et Solander

Corallina granifera Ellis et Solander

Falkenbergia rufolanosa stadio (Harvey) Schmitz

Gelidiella ramellosa (Kützing) J. Feldmann et Hamel

Gelidium pusillum (Stackhouse) Le Jolis

Griffithsia schousboei Montagne

Jania adhaerens Lamouroux

Jania rubens (Linné) Lamouroux

Kallymenia requienii J. Agardh

Laurencia microcladia Kützing

Laurencia pelagosae (Schiffner) Ercegovic

Lithophyllum expansum Philippi sensu Lemoine

Lithophyllum lichenoides Philippi

Lithothamnion corallioides Crouan et Crouan

Lithothamnion valens Foslie

Lophosiphonia subadunca (Kützing) Falkenberg

Mesophyllum lichenoides (Ellis) Lemoine

Peyssonnelia bornetii Boudouresque et Denizot

Peyssonnelia rosa-marina Boudouresque et Denizot

Peyssonnelia rubra (Grevilie) J. Agardh

Peyssonnelia squamaria (Gmelin) Decaisne

Phyllophora crispa (Hudson) Dixon

Polysiphonia subulifera (C. Agardh) Harvey

Sphaerococcus coronopifolius Stackhouse

Spongites hauckii (Rothpletz) Ballesteros

Spongites ramulosa (Philippi) Kützing

Tricleocarpa oblongata (Ellis et Sol.) Huisman et Borowitzka

Vidalia volubilis (Linné) J. Agardh

$\begin{array}{lllll}0 & 0 & 0 & 1 & 1 \\ 0 & 0 & 0 & 0 & 0 \\ 0 & 1 & 0 & 0 & 1 \\ 0 & 1 & 0 & 0 & 2 \\ 0 & 1 & 0 & 0 & 0 \\ 0 & 2 & 1 & 0 & 0 \\ 0 & 1 & 0 & 0 & 1 \\ 3 & 1 & 0 & 0 & 1 \\ 0 & 0 & 0 & 1 & 1 \\ 0 & 1 & 0 & 0 & 0 \\ 0 & 1 & 0 & 0 & 1 \\ 0 & 1 & 0 & 0 & 1 \\ 0 & 1 & 0 & 0 & 0 \\ 0 & 0 & 1 & 0 & 1 \\ 0 & 2 & 0 & 0 & 1 \\ 0 & 1 & 0 & 0 & 0 \\ 0 & 0 & 3 & 0 & 1 \\ 0 & 2 & - & - & - \\ 0 & 1 & 0 & 0 & 0 \\ 0 & 0 & 0 & 1 & 0 \\ 0 & 1 & 0 & 0 & 1 \\ 0 & 1 & 0 & 1 & 1 \\ 0 & 0 & 0 & 1 & 3 \\ 0 & 0 & 0 & 2 & 1 \\ 0 & 0 & 0 & 0 & 0 \\ 0 & 0 & 0 & 1 & 1 \\ 0 & 2 & 0 & 0 & 0 \\ 0 & 0 & 0 & 0 & 0 \\ 0 & 1 & 0 & 0 & 1 \\ 0 & 1 & - & - & - \\ 0 & 1 & - & - & - \\ 0 & 0 & 0 & 1 & 0 \\ 0 & 0 & 0 & 0 & 0\end{array}$

Phaeophyta

Aglaozonia chilosa stadio Falkenberg

Cladostephus hirsutus (Linné) Prud'homme van Reine

Cystoseira balearica Sauvageau

Cystoseira compressa (Esper) Gerloff et Nizamuddin

Cystoseira ercegovicii Giaccone

Cystoseira mediterranea Sauvageau

Cystoseira spinosa Sauvageau

Cystoseira zosteroides (Turner) C. Agardh

Dictyopteris membranacea (Stackhouse) Batters

Dictyota dichotoma (Hudson) Lamouroux

Dictyota dichotoma v. intricata (C. Agardh) Greville

Halopteris filicina (Grateloup) Kützing

Halopteris scoparia (Linné) Sauvageau

Lobophora variegata (Lamouroux) Womersley

Padina pavonica (Linné) Thivy

Phyllariopsis brevipes (C. Agardh) Henry et South

Sargassum hornschuchii $\mathrm{C}$. Agardh

Zanardinia prototypus (Nardo) Nardo

Zonaria tournefortii (Lamouroux) Montagne

Chlorophyta

Anadyomene stellata (Wulfen) C. Agardh

Caulerpa prolifera (Forskal) Lamouroux

Chaetomorpha capillaris (Kützing) Boergesen

Cladophora coelothrix Kützing

Cladophoropsis monodensis (Kützing) Boergesen

Botanica Marina / Vol. 35 / 1992 / Fasc. 6 
Table I. Continued.

\begin{tabular}{|c|c|c|c|c|c|}
\hline Species & $\mathrm{BAC}$ & FUN & AV & $\mathrm{CT}$ & AM \\
\hline Codium bursa J. Agardh & 0 & 2 & 0 & 0 & 0 \\
\hline Codium vermilara (Olivi) Delle Chiaje & 0 & 2 & 0 & 0 & 0 \\
\hline Dasycladus vermicularis (Scopoli) Krasser & 0 & 0 & 0 & 1 & 3 \\
\hline Flubellia petiolata (Turra) Nizamuddin & 1 & 1 & 1 & 1 & 2 \\
\hline Halimeda tuna (Ellis et Solander) Lamouroux & 0 & 2 & 1 & 1 & 3 \\
\hline Microdictyon tenuius (J. Agardh) Decaisne & 0 & 1 & 0 & 0 & 0 \\
\hline Palmophyllum crassum (Naccari) Rabenhorst & 1 & 0 & 1 & 1 & 1 \\
\hline Valonia utricularis (Roth) C. Agardh & 0 & 2 & 1 & 3 & 1 \\
\hline \multicolumn{6}{|l|}{ Magnoliophyta } \\
\hline Cymodocea nodosa (Ucria) Ascherson & 0 & 2 & 1 & 1 & 0 \\
\hline Posidonia oceanica (Linné) Delile & 0 & 2 & 0 & 0 & 0 \\
\hline Zostera noltii Hornemann & 0 & 2 & 0 & 0 & 0 \\
\hline
\end{tabular}

Cytotoxic activity was found in $35 \%$ of the total macrophytes screened and it was also outstanding $(54 \%)$ in the green algae. The encrusting red alga Peyssonnelia rosa-marina, the brown alga Dictyopteris membranacea and the green alga Valonia utricularis were the species with the highest cytotoxic activity.

Antimitotic activity was common in all the algal divisions, but not activity was found in the seagrasses. Activity was found in between 45 and $55 \%$ of all tested species, depending on the algal group considered. The maximum of activity was found in the green algae Dasycladus vermicularis, Halimeda tuna, Caulerpa prolifera and Flabellia petiolata, and the red algae Peyssonnelia bornetii and Amphiroa rigida.

No previous records on antimitotic and cytotoxic properties of Mediterranean macrophytes have appeared in the literature, except those dealing with particular species present in other areas of the world. Different antimitotic and cytotoxic compounds have been isolated from Halimeda tuna, Flabellia petiolata and Caulerpa prolifera (Paul and Fenical 1991). These three plants exhibited strong antimitotic and cytotoxic activities in our screening tests. The brown alga Dictyota dichotoma, for which previously known cyto-

\section{References}

Barbagallo, C., M. Cormaci, G. Furnari, R. Gismondo, G. Majorana and M. A. Toscano. $1979 \mathrm{a}$. Attività antibatterica di estratti di alghe marine delle coste orientali della Sicilia: I contributo. Pubbl. Ist. Bot. Univ. Catania: 1-5.

Barbagallo, C., A. Battiato, M. Cormaci, G. Furnari and G. Majorana. $1979 \mathrm{~b}$. Alghe marine della Sicilia orientale di interesse officinale. Boll. Accad. Gioenia Sci. Nat. Catania ser IV $13(7-8): 311-321$.

Bergquist, P. R. and J. J. Bedford. 1978. The incidence of antibacterial activity in marine Demospongiae: systematic and geographic considerations. Mar. Biol. 46: 215-221. toxic metabolites have been reported (Enoki et al. 1980), was also cytotoxic in our tests. On the contrary, Anadyomene stellata did not show any sign of antimitotic activity in our tests, whilst specimens from Florida gave a strong antineoplastic response (Hodgson 1984). Peyssonnelia rosa-marina, Dictyopteris membranacea and Valonia utricularis were found to be highly cytotoxic, whilst Amphiroa rigida, Peyssonnelia bornetii and Dasycladus vermicularis had strong antimitotic activity. More research is needed on this subject before any conclusion can be drawn.

\section{Acknowledgements}

The authors are indebted to Dr R. Hughes, Ms C. Acebal, Ms M. Bardaji, Ms M. García and Ms R. López who participated in the screenings. Dr X. Turón, Dr J. M. Tur, Dr K. Rinehart, Dr R. Brusca and Ms $D$. Rosell took part in the field work. The crew of the B/O García del Cid provided technical assistance during the survey.

This study was supported by the projects ECOFARM and CICYT MAR91-0528.

Bernard, P. and R. Clement. 1983. Bringing to evidence antibiotic substances from Posidonia oceanica. Rev. Int. Océanogr. Méd. 70-71: 33-37.

Bernard, P. and D. Pesando. 1989. Antibacterial and antifungal activity of extracts from the rhizomes of the Mediterranean seagrass Posidonia oceanica. Bot. Mar. 32: 85-88.

Berti, T., G. Fassina and S. Pignatti. 1963. Attività antimicrobica di alghe della costa veneta. Giorn. Bot. Ital. 70: 609612.

Burkholder, P. R.. L. M. Burkholder and L. R. Almodóvar. 1960. Antibiotic activity of some marine algae of Puerto Rico. Bot. Mar. 2: 149-156. 
Caccamese, S. and R. Azzolina. 1979. Screening for antimicrobial activities in marine algae from eastern Sicily. Planta Medica 37: 333-339.

Caccamese, S., R. Azzolina, G. Furnari, M. Cormaci and S. Grasso. 1980. Antimicrobial and antiviral activities of extracts from Mediterranean algae. Bot. Mar. 23: 285-288.

Caccamese, S., R. Azzolina, G. Furnari, M. Cormaci and S. Grasso. 1981. Antimicrobial and antiviral activities of some marine algae from Eastern Sicily. Bot. Mar. 24: 365-367.

Caccamese, S., R. M. Toscano, G. Furnari and M. Cormaci. 1985. Antimicrobial activities of red and brown algae from Southern Italy coast. Bot. Mar. 28: 505-507.

Conover, J. T. and J. M. Sieburth. 1963. Effect of Sargassum distribution on its epibiota and antibacterial activity. Bot. Mar. 6: 147-157.

Enoki, N., K. Tsuzuki, S. Okamura, R. Ishida and T. Matsumoto. 1983. New antimicrobial diterpenes, dictyol $F$, antiepidictyol $\mathrm{F}$, from the brown alga Dictyota dichotoma. Chem. Lett: $1267-1630$.

Hodgson, L. M. 1984. Antimicrobial and antineoplastic activity in some South Florida seaweeds. Bot. Mar. 27: 387-390.

Hornsey, I. S. and D. Hide. 1974. The production of antimicrobial compounds by British marine algae. I. Antibioticproducing marine algae. Br. Phycol. J. 9: 353-361.

Hornsey, I. S. and D. Hide. 1976. The production of antimicrobial compounds by British marine algae. II. Seasonal variation in production of antibiotics. Br. Phycol. J. 11: $63-67$.

Khaleafa, A. F., M. A. M. Kharboush, A. Metwalli, A. F. Mohsen and A. Serwi. 1975. Antibiotic (fungicidal) action from extracts of some seaweeds. Bot. Mar. 18: 163-165.

Munro, M. H. G., R. T. Luibrand and J. W. Blunt. 1991. The search for antirival and anticancer compounds from marine organisms. In: (P. J. Scheuer, ed.) Bioorganic Marine Chemistry: 93-176. Springer Verlag. Berlin.

Naqvi, S. W., A. Solimabi, S. Y. Kamat, L. Fernandes, C. V. G. Reddy, D. S. Bhakuni and B. N. Dhawan. 1980. Screening of some marine plants from the Indian coast for biological activity. Bot. Mar. 24: 51-55.
Paul, V. J. and W. Fenical. 1986. Chemical defense in tropical green algae, order Caulerpales. Mar. Ecol. Progr. Ser. 33: $255-264$

Paul, V. J. and W. Fenical. 1991. Natural products chemistry and chemical defense in tropical marine algae of the phylum Chlorophyta. In: (P. J. Scheuer, ed.) Bioorganic Marine Chemistry: 1-29. Springer Verlag. Berlin.

Pesando, D. and B. Caram. 1984. Screening of marine algae from the French Mediterranean coast for antibacterial and antifungal activity. Bot. Mar. 27: $381-386$.

Porzi, G. and E. Minelli. 1975. Attività antibatterica e presenza di mercurio in dodici specie di alghe marine. Boll. Soc. It. Biol. Sper. 5I: $1591-1995$.

Reichelt, J. L. and M. A. Borowitzka. 1983. Antimicrobial activity from marine algae: results of a large-screening programme. Proc. Int. Seaweed Symp. Il: 158-168.

Rinehart Jr., K. L., P. D. Shaw, L. S. Shield, J. B. Gloer, G. C. Harbour, M. E. S. Koker, D. Samain, R. E. Schwartz, A. A. Tymiak, D. L. Weller, G. T. Carter, M. H. G. Munro, R. G. Hughes Jr., H. E. Renis, E. G. Swynenberg, D. A. Stringfellow, J. J. Vavra, J. H. Coats, G. E. Zurenko, S. L. Kuentzel, L. H. Li, G. J. Bakus, R. C. Brusca, L. L. Craft, D. N. Young and J. L. Connor. 1981. Marine natural products as sources of antivirus, antimicrobial and antineoplastic agents. Pure Appl. Chem. 53: 795-817.

Rinehart Jr., K. L., J. B. Gloer Jr., G. R. Wilson, R. G. Hughes Jr., H. L. Li, H. E. Renis and J. P. McGovren. 1983. Antiviral and antitumor compounds from tunicates. Marine pharmacology: drugs from the sea. Fed. Proc. 42 (1): 87-90.

Schröeder, A. C., R. G. Hughes Jr. and A. Block. 1981. Synthesis and biological effects of acyclic pyramidine nucleoside analogues. J. Med. Chem. 24: 1078-1083.

Serarols, M. D., M. C. Hernández and J. A. Seoane-Camba. 1982. Sobre la actividad antibiótica de ciertas especies de algas del Mediterráneo. Collect. Bot. 12 (2): 919-927.

Thompson, J. E., R. P. Walker and J. Faulkner. 1985. Screening and bioassays for biologically-active substances from forty marine sponge species from San Diego, California, U. S. A. Mar. Biol. 88: $11-21$. 